\title{
LA ENTREGA DEL PODER DE MOTECUHZOMA \\ UNA PROPUESTA CRÍTICA
}

\section{THE HANDOVER POWER FROM MOTECUHZOMA}

\section{A CRITICAL PROPOSAL}

\author{
Miguel Pastrana Flores \\ Universidad Nacional Autónoma de México \\ Instituto de Investigaciones Históricas \\ micquetl@unam.mx \\ ORCID: 0000-0002-7136-8780
}

\section{Resumen}

Este artículo es una revisión crítica de la acción de entrega del poder y sumisión atribuida a Motecuhzoma Xocoyotzin, en favor de Carlos I de España, por intermediación del capitán Hernando Cortés. Este pasaje fundamental en la historia de la conquista de Tenochtitlan ha tenido importantes y trascendentes implicaciones legales, políticas e historiográficas hasta el día de hoy, y por ello ha sido objeto de diversos análisis desde la perspectiva de la cultura europea. Sin embargo, poco se ha explorado el problema, no ya desde la perspectiva jurídica, política, documental e historiográfica española, sino desde lo que se sabe acerca de las instituciones, creencias y prácticas políticas de los antiguos nahuas. Este trabajo estudia la perspectiva náhuatl de la cuestión.

Palabras clave: Motecuhzoma, Hernando Cortés, Conquista de México, poder político, pérdida del poder, tlahtoani, Excan Tlahtoloyan.

\begin{abstract}
This article is a critical review of the act of handing over power and submission attributed to Motecuhzoma Xocoyotzin, in favor of Carlos I of Spain, through the intermedition of Captain Hernando Cortés. This fundamental passage in the history of the conquest of Tenochtitlan has had significant legal, political and historiographic implications to this day; therefore, it has been the subject of various analyzes from the perspective of European culture. However, the problem has been little explored, not only from the Spanish legal, political, documentary and historiographical perspective, but also not about what is known about the institutions, beliefs and political practices of the ancient Nahuas. This paper studies the Nahuatl perspective of the matter.
\end{abstract}

Keywords: Motecuhzoma, Hernando Cortés, Conquest of Mexico, political power, loss of power, tlahtoani, Excan Tlahtoloyan.

\section{Información del artículo}

Recibido: 14 de enero de 2020.

Aceptado: 5 de marzo de 2020.

DOI: 10.22201/iih.24486922e.2020.62.72727 


\section{El problema}

Entre los diversos acontecimientos notables del proceso de la conquista militar de Tenochtitlan por las fuerzas de la alianza hispano-indígena destaca la acción de entrega del poder y sumisión atribuida a Motecuhzoma Xocoyotzin, en favor del rey Carlos I de España, por intermedio del capitán Hernando Cortés. El evento al que hago referencia es ampliamente conocido entre los especialistas; sin embargo, con fines expositivos es conveniente recordarlo brevemente, así como las principales fuentes para su conocimiento. ${ }^{1}$

De acuerdo con la Segunda relación de Cortés en tres diferentes momentos Motecuhzoma pronunció sendos discursos en los cuales expresó las mismas ideas, con variantes menores, sobre el tema que se estudia. El primero de ellos fue a la llegada a Tenochtitlan de los castellanos; el segundo es el acto mismo de entrega del mando y el tercer momento se corresponde con el intento de remoción de las imágenes sagradas de los dioses nahuas en el Huey teocalli o Templo Mayor de Tenochtitlan. Si bien la cronología de la conquista española presenta imprecisiones, de manera general puede decirse que la llegada a Tenochtitlan fue el 8 de noviembre de 1519, mientras la entrega del poder y el intento de mover las imágenes del Templo Mayor ocurrieron entre los meses de enero y abril de 1520. Según los textos cortesianos, el huey tlahtoani declaró que los mexicas eran extranjeros, que fueron traídos de lejanas tierras por un "grand señor o rey" "cuyos vasallos todos eran", ${ }^{2}$ el cual volvió a su lugar de origen mientras los mexicas se quedaron en la cuenca de México; tiempo después el "grand señor" regresó con la intención de llevarse consigo a los mexicas a su tierra de origen, pero ellos se negaron y él se volvió a retirar no sin antes anunciar que regresaría a reclamar el mando, "se volvió y dejó dicho que tornaría o inviaría con tal poder que los pudiese costriñir y atraer a su servicio". ${ }^{3}$ Según Cortés, Motecuhzoma identificó a este oscuro "grand señor" con

${ }^{1}$ Una visión sintética de la historia de la conquista puede verse en Jaime Montell, La caída de México-Tenochtitlán (México: Joaquín Mortiz, 2003), o José Luis Martínez, Hernán Cortés: versión abreviada (México: Fondo de Cultura Económica, 1992). Para tener un panorama más amplio, véanse las obras clásicas de William $\mathrm{H}$. Prescott, Historia de la conquista de México, 2 v., traducción de José María González de la Vega, con anotaciones de Lucas Alamán (Buenos Aires: Imán, 1944), o el volumen cuarto de Manuel Orozco y Berra, Historia antigua y de la conquista de México, 2a. ed., 4 v., edición y estudio previo de Ángel M. Garibay, biografía y bibliografías de Miguel León-Portilla (México: Porrúa, 1978).

${ }^{2}$ Hernán Cortés, "Segunda relación", Cartas de relación, edición, introducción y notas de Ángel Delgado Gómez (Madrid: Castalia, 1993), 210-211.

${ }^{3}$ Cortés, Cartas, “Segunda relación”, 227. 
Carlos I, por lo cual le debía obediencia, pues "tengo por cierto, y ansí lo debéis vosotros tener, que aquéste es el señor que esperábamos" ${ }^{4} \mathrm{y}$, en tanto entraba en contacto directo con él, entregaba el mando político al capitán. Además, en la segunda ocasión, reunidos los principales gobernantes del Excan Tlahtoloyan "el lugar del mando de triple sede" o Triple Alianza, Motecuhzoma hizo entrega del poder en favor del rey de España y los exhortó a obedecer a Cortés; en palabras de este último, el mexica dijo: "Y mucho os ruego, pues a todos es notorio todo esto, que así como hasta aquí a mí me habéis tenido y obedescido por señor vuestro, de aquí adelante tengáis y obedezcáis a este grand rey pues él es vuestro señor natural, y en su lugar tengáis a éste su capitán". ${ }^{5}$

Incluso en el tercero de los textos mencionados, el correspondiente al intento de remover las imágenes de los dioses nahuas, se insinúa que los mexicas podrían ser parientes de los hispanos, pues se dice que ambos grupos venían del mismo lugar y como los mexicas habían emigrado de ese sitio hacía mucho tiempo, quizás habían olvidado aspectos de la religión original, pues, según Cortés

me respondieron que ya me habían dicho que ellos no eran naturales desta tierra y que había muchos tiempos que sus predecesores habían venido a ella; y que bien creían que podían estar errados en algo de aquello que tenían [creían] por haber tanto tiempo que salieron de su naturaleza [su lugar de origen], y que yo, como más nuevamente venido, sabría las cosas que debían tener y creer mejor que ellos, que se las dijese e hiciese entender, que ellos harían lo que yo les dijese que era lo mejor. ${ }^{6}$

De esta forma, según el capitán extremeño, el tlahtoani mexica aceptó entregar el mando político, no sólo de Tenochtitlan, sino de todo el Excan Tlahtoloyan, en favor de la monarquía peninsular. Sin duda, para Cortés se trata de un acto de vasallaje de Motecuhzoma, el cual también implica una completa entrega, cesión, transferencia o traslado de la soberanía del tlahtoani mexica al rey de España, acción a la que se atribuye plena formalidad y valor legal, pues afirma que fue hecha ante escribano y con la firma de testigos, pues dice el capitán que "todo pasó ante un escribano público y lo asentó por abto en forma y yo le pedí ansí por testimonio en presencia de

${ }^{4}$ Cortés, Cartas, “Segunda relación”, 228.

${ }^{5}$ Cortés, Cartas, “Segunda relación”, 228.

${ }^{6}$ Cortés, Cartas, “Segunda relación”, 239. 
muchos españoles". 7 Aunque más adelante afirma que los autos desaparecieron durante la retirada de la llamada "Noche Triste", ya que "se perdieron todas las escripturas y abtos que yo había hecho con los naturales destas partes". ${ }^{8}$ Por si fuera poco, recordemos que, según el propio capitán, seis días después de la llegada a Tenochtitlan, apresó al huey tlahtoani, el cual fue recluido en cierta sala de sus aposentos bajo estrecha vigilancia de los castellanos.

La aceptación tanto de la realidad fáctica como del valor legal de este pasaje de entrega del poder pronto fue uno de los títulos más sólidos del dominio español sobre tierras americanas, en específico sobre la naciente Nueva España, la cual fue concebida como fundada sobre los antiguos dominios del Excan Tlahtoloyan; también fue usada por Cortés para justificar la campaña militar contra Tenochtitlan después de la "Noche Triste" como una "guerra justa", pues se trataba de someter a "vasallos rebeldes". ${ }^{9}$ Desde entonces, muchos autores - como Juan Ginés de Sepúlveda en el siglo XVI; William H. Prescott y Manuel Orozco y Berra en el siglo xix; Carlos Pereyra, Juan Miralles y Bernard Grunberg en el siglo xx, o Jaime Montell, Germán Vázquez y José Javier Esparza en el siglo XXI- han aceptado este episodio como una verdad indudable y las palabras de Cortés como fieles referentes de dicho evento. ${ }^{10}$

Sin embargo, este pasaje del proceso político de la conquista y el texto cortesiano que lo refiere han sido objeto de amplia discusión. Así, diversos estudiosos, ya desde el mismo siglo xvI, han cuestionado tanto la verosimilitud del relato, y por lo tanto su veracidad, así como su factibilidad y su

${ }^{7}$ Cortés, Cartas, "Segunda relación”, 229.

${ }^{8}$ Cortés, Cartas, "Segunda relación”, 288.

${ }^{9}$ Véase Silvio Zavala, Hernán Cortés ante la justificación de su conquista, en Toribio Esquivel Obregón, Hernán Cortés y el derecho internacional en el siglo XVI, 2a. ed., presentación de Silvio Zavala (México: Porrúa, 1985), 128.

${ }^{10}$ Véanse Juan Ginés de Sepúlveda, Historia del Nuevo Mundo, introducción, traducción y notas de Antonio Ramírez de Verger (Madrid: Alianza, 1987), 157-159; Prescott, Historia de la conquista, I:407-408; Orozco y Berra, Historia antigua, v. IV; Carlos Pereyra, Hernán Cortés, 4a. ed., prólogo de Martín Quirarte (México: Porrúa, 2006), 153; Juan Miralles, Hernán Cortés, inventor de México, prólogo de Fernando R. Lafuente ([S. 1.]: Folio; ABC, 2004), I:184-185; Bernard Grunberg, Histoire de la conquête du Mexique (París: L’Harmattan, 1995), 103; Jaime Montell, La conquista de México Tenochtitlan (México: Miguel Ángel Porrúa, 2001), 513-514; Germán Vázquez Chamorro, Moctezuma (Madrid: Algaba, 2006), 235-240; José Javier Esparza, La cruzada del océano. La gran aventura de la Conquista de América, 2a. ed. (Madrid: La Esfera de los Libros, 2017), 319-320. 
legalidad, ya que de forma temprana autores como Fernando González de Oviedo y Bartolomé de las Casas externaron en sus obras muchas dudas sobre las palabras y acciones de Cortés, pues al decir del obispo de Chiapas "es manifiesto que es completamente falso que Moctezuma cedió la jurisdicción a los Reyes de España lo que, por derecho de gentes le pertenecía [... ]". ${ }^{11}$ La polémica ha continuado hasta nuestros días con los trabajos de Eulalia Guzmán, Víctor Frankl, John H. Elliott, Antony Pagden, Susan Gillespie y Matthew Restall, ${ }^{12}$ entre otros, quienes han cuestionado el relato de las Cartas de relación desde las más diversas trincheras ideológicas y académicas, ya sea calificándolo o implicándolo de ser apócrifo, de invención literaria, de ficción legal, de mentira o de maliciosa tergiversación. Mientras que otros, como Hugh Thomas, Michel Graulich o Valeria Añón, ${ }^{13}$ si bien han aceptado un núcleo fáctico en el relato cortesiano, advierten que se trata de un texto tendencioso o de plano manipulado, que seguramente refleja más la interpretación interesada de Cortés para justificar sus acciones que las auténticas palabras del tlahtoani mexica. Algunos autores más, como Silvio Zavala, resaltan que el mandatario tenochca y los otros gobernantes del Excan Tlahtoloyan estaban presos y bajo constante coerción,

${ }^{11}$ Bartolomé de las Casas, De thesauris, fijación del texto, traducción, introducción e índices de Ángel Losada, notas e índices por Martín Lassegue (Madrid: Alianza Editorial, 1992), cap. XXXII, 351. Gonzalo Fernández de Oviedo y Valdés, Historia general y natural de las Indias, edición de Juan Pérez de Tudela (Madrid: Atlas, 1959), IV:259.

${ }^{12}$ Eulalia Guzmán, "Prólogo”, “Aclaraciones y rectificaciones”, en Relaciones de Hernán Cortés a Carlos V sobre la invasión de Anáhuac, edición de Eulalia Guzmán (México: Libros Anáhuac, 1958); Víctor Frankl, "Imperio particular e imperio universal en las cartas de relación de Hernán Cortés”, Cuadernos Hispanoamericanos (Instituto de Cultura Hispánica, Madrid), n. 165 (septiembre 1963): 443-482; John H. Elliott, "Cortés, Velázquez and Charles V”, en Letter from Mexico, de Hernán Cortés, XI-XXXVII, trad., ed. y una nueva introducción de Anthony Pagden (New Haven: Yale University Press, 2001); John H. Elliott, "The Mental World of Hernán Cortés”, Royal Historical Society Transactions. Fifth Series, n. 17 (1967): 41-58; Anthony R. Pagden, "Introduction” y "Notes", en Letter from Mexico, de Hernán Cortés, XxxiX-LXxi, trad., ed. y una nueva introducción de Anthony Pagden (New Haven: Yale University Press, 2001); Susan Gillespie, Los reyes aztecas. La reconstrucción del gobierno en la historia mexica, traducción de Stella Mastrangelo (México: Siglo XXI, 1986); Matthew Restall, Cuando Moctezuma conoció a Cortés. La verdad del encuentro que cambió la historia, traducción de José Eduardo Latapí (México: Taurus, 2019), passim.

${ }^{13}$ Hugh Thomas, La conquista de México, traducción de Víctor Alba (Barcelona: Patria, 1994), 324; Michel Graulich, Moctezuma. Apogeo y caída del imperio azteca, traducción de Tessa Brisac (México: Era; Instituto Nacional de Antropología e Historia, 2014), 422-424; Valeria Añón, "Prólogo” y "Notas”, en Segunda carta de relación y otros textos, de Hernán Cortés (Buenos Aires: Corregidor, 2010), nota 137, 158. 
y por ello se vieron obligados a actuar como Cortés lo indicaba. ${ }^{14}$ Por su parte Antonio de Solís sostiene que, si bien Motecuhzoma rindió vasallaje al rey de España, en realidad no pensaba cumplir su palabra, pues "se debe de creer que Motezuma, por más que mirase al rey de España como legítimo sucesor de aquel imperio, no tuvo intento de cumplir lo que ofrecía. Su mira fue deshacerse de los españoles". ${ }^{15}$ Incluso Francisco Martínez piensa que Motecuhzoma pudo haber sufrido del "síndrome de Estocolmo" y por ello se identificó con los intereses de sus captores. ${ }^{16}$

En todo caso, los diversos estudiosos han vinculado el análisis de los textos cortesianos y las acciones de su autor con un contexto jurídico y político más amplio; así se han establecido nexos con la tradición de las Siete partidas de Alfonso X, con la teoría de la autoridad papal, con la idea de imperio universal, con el Requerimiento elaborado por Juan de Palacios Rubios o el concepto de Traslatio imperii. ${ }^{17}$ Sin duda la polémica y el estudio de este tópico seguirá por largo tiempo.

Sin embargo, poco se ha explorado sobre el problema, no ya desde la perspectiva jurídica, política, documental e historiográfica española, sino desde lo que se sabe acerca de las instituciones, creencias y prácticas políticas

${ }^{14}$ Zavala, Hernán Cortés, 127: "El conquistador [...] exige a Moctezuma el vasallaje en favor del soberano de Castilla. Por superstición o por temor, el Emperador azteca reúne a sus notables y, en acto que Cortés recogió ante escribano, presta obediencia [...]”.

${ }^{15}$ Antonio de Solís y Rivadeneira, Historia de la conquista de México, población y progresos de la América septentrional, conocida por el nombre de Nueva España, prólogo y apéndices de Edmundo O’Gorman, notas de José Valero Silva, 5a. ed. (México: Porrúa, 1990), libro IV, cap. III, 205.

${ }^{16}$ Francisco Martínez Hoyos, Breve historia de Hernán Cortés (Madrid: Nowtilus, 2014), 152. Para los múltiples problemas que implica el concepto mismo de dicho "síndrome", véase Lucía Ester Rizo-Martínez, "El síndrome de Estocolmo: una revisión sistemática”, Clínica y Salud 29 (Madrid), n. 2 (julio 2018), http://dx.doi.org/10.5093/clysa2018a12.

${ }^{17}$ La bibliografía sobre los "Justos títulos" de la conquista es muy extensa, para una visión general. Véanse los trabajos de Silvio Zavala, La filosofía política en la Conquista de América, prólogo de Rafael Altamira, 3a. ed. (México: Fondo de Cultura Económica, 1977), y Las instituciones jurídicas en la conquista de América, 3a. ed. (México: Porrúa, 1988); José Valero Silva, El legalismo de Hernán Cortés como instrumento de su conquista (México: Universidad Nacional Autónoma de México, Instituto de Investigaciones Históricas, 1965); Víctor Frankl, "Hernán Cortés y la tradición de las Siete Partidas”, Revista de Historia de América (Instituto Panamericano de Geografía e Historia, México), n. 53-54 (julio-diciembre 1962): 9-74; Richard Konetzke, América Latina II. La época colonial, traducción de Pedro Scaron, 25a. ed. (México: Siglo XXI, 1995), especialmente "Títulos jurídicos de la colonización de América”, 20-33; y Anthony Pagden, Señores de todo el mundo. Ideologías del imperio en España, Inglaterra y Francia en los siglos, XVI, XVII y XVIII, traducción de M. Dolors Gallart Iglesias (Barcelona: Península, 1997), 45-86. 
de los antiguos nahuas. Dicho en otros términos, es del todo pertinente examinar si la pretendida entrega, cesión, traslado, transferencia o enajenación del mando político por parte de Motecuhzoma en favor de Carlos I está en consonancia con lo que se conoce del mundo político de los antiguos nahuas y, de manera complementaria, preguntarse qué sentido tendría esta supuesta cesión de mando y soberanía dentro de las concepciones, prácticas e instituciones vinculadas con el poder político de la cultura náhuatl.

Pero antes de ello es adecuado hacer unas breves observaciones sobre las fuentes de conocimiento del tema. Sin duda, la fuente fundamental es la "Segunda relación" de Hernán Cortés, fechada el 30 de octubre de 1520 y publicada por vez primera en 1522, por lo cual es el testimonio más cercano en el tiempo y, además, es un texto del cual parten otros. ${ }^{18}$ Después de la "Segunda relación", los principales referentes de tradición hispana sobre el tema son la Historia de la conquista de México de Francisco López de Gómara, publicada en 1552, que sigue muy de cerca las Cartas de relación sólo con variantes menores en los pasajes mencionados, y la Historia verdadera de la conquista de Nueva España de Bernal Díaz del Castillo, terminada hacia 1568, que si bien pretende desmentir y corregir la obra de Gómara, en lo general la sigue muy de cerca sin variantes significativas, ${ }^{19}$ pues, como dice Ángel Delgado Gómez: "El texto de la Historia verdadera sigue al de Gómara, que a su vez sigue al de Cortés”. ${ }^{20}$ Otras obras de importancia son la Crónica de la Nueva España de Francisco Cervantes de Salazar, primer cronista de la ciudad de México, que escribe cuando aún vivían varios con-

${ }^{18}$ Una investigación fundamental de la visión de la conquista de Cortés en sus Cartas de relación y el impacto historiográfico de las mismas en el siglo XVI puede verse en Ramón Iglesia, Cronistas e historiadores de la Conquista de México. El ciclo de Hernán Cortés, 1a. reimp. (México: El Colegio de México, 1990).

${ }^{19}$ Francisco López de Gómara, Historia de la conquista de México, prólogo y cronología de Jorge Gurría Lacroix, 2a. ed. (Caracas: Ayacucho, 1991), cap. XCII, 145-146; Bernal Díaz del Castillo, Historia verdadera de la conquista de la Nueva España, edición, presentación, estudio y notas de Guillermo Serés, ensayo introductorio de Miguel León-Portilla, 2 v. (México: Academia Mexicana de la Lengua, 2014), cap. LxxxıX, CI, I:315-316, 375-377.

${ }^{20}$ Ángel Delgado Gómez, "Introducción” y “Notas”, en Cartas de relación, de Hernán Cortés, edición, introducción y notas de Ángel Delgado Gómez (Madrid: Castalia, 1993), nota 249, 228; esto fue señalado inicialmente por Ramón Iglesia, "Dos estudios sobre el mismo tema”, en Ramón Iglesia, El hombre Colón y otros ensayos, introducción de Álvaro Matute (México: Fondo de Cultura Económica, 1986), 109-138; véase también Guillermo Serés, "Estudio Bernal Díaz del Castillo y la Historia verdadera", "Notas" y "Notas complementarias", en Díaz del Castillo, Historia verdadera de la conquista de la Nueva España, II: 1131-1132, nota 6; I:377-378. 
quistadores que eran regidores de la ciudad, mismos que fueron sus informantes y avalaron su obra; el humanista, al igual que Bernal, pretende corregir a Gómara, pero también lo sigue estrechamente en las partes que nos interesan. ${ }^{21}$ Por su parte, las obras de otros soldados cronistas e historiadores - como la Relación de méritos y servicios de Bernardino Vázquez de Tapia, la Relación de algunas cosas de las que acaecieron al Muy Ilustre Señor Don Hernando Cortés, marqués del Valle de Andrés de Tapia y la Relación breve de la conquista de la Nueva España de fray Francisco de Aguilar- poco agregan a la discusión, pues simplemente dicen que Motecuhzoma entregó el poder o no mencionan el acontecimiento. ${ }^{22}$ También están las declaraciones recabadas durante el juicio de residencia de Cortés, las cuales aportan algunos matices de interés, no tanto sobre la entrega del poder, sino sobre los eventos relacionados. ${ }^{23}$ También existe un impreso temprano, de fines de 1521 o principios de 1522, donde se menciona el encuentro entre el tlahtoani y el capitán, en el cual no se habla de sometimiento alguno de "Madozoma", sino que éste propone a sus "consejeros" que se permita a los castellanos entrar a Tenochtitlan, por lo cual fue depuesto y ejecutado por los indígenas; posteriormente su hijo asumió el mando. ${ }^{24}$

En la historiografía de tradición indígena los pasajes claros y explícitos de entrega del poder brillan por su ausencia. ${ }^{25}$ Así, no hay registro, men-

${ }^{21}$ Francisco Cervantes de Salazar, Crónica de la Nueva España, prólogo, de Juan Miralles Ostos (México: Porrúa, 1985), libro Iv, cap. xLv, 371-373.

${ }^{22}$ Bernardino Vázquez de Tapia, Relación de méritos y servicios del conquistador Bernardino Vázquez de Tapia, estudio y notas de Jorge Gurría Lacroix (México: Universidad Nacional Autónoma de México, 1972); Andrés de Tapia, Relación de algunas cosas de las que acaecieron al Muy Ilustre Señor Don Hernando Cortés, Marqués del Valle, desde que se determinó ir a descubrir tierra en la Tierra Firme del mar Océano, en Crónicas de la Conquista de México, introducción, selección y notas de Agustín Yáñez (México: Universidad Nacional Autónoma de México, 1939), 41-96; Francisco de Aguilar, Relación breve de la conquista de la Nueva España, Serie de Historiadores y Cronistas de Indias 7, edición, estudio preliminar, notas y apéndices por Jorge Gurría Lacroix (México: Universidad Nacional Autónoma de México, Instituto de Investigaciones Históricas, 1980), 224.

${ }^{23}$ Véase Documentos cortesianos, edición de José Luis Martínez, 4 v. (México: Fondo de Cultura Económica; Universidad Nacional Autónoma de México, 1990), especialmente el volumen II, 1526-1545, Sección IV. Juicio de Residencia; Thomas, La conquista, 699-700, reproduce el testimonio de Francisco de Flores, que concuerda casi punto por punto con el de Cortés, lo que hace pensar que había leído, y seguido, la Segunda relación del marqués del Valle.

${ }^{24}$ Restall, Cuando Moctezuma conoció, 77-78.

${ }^{25}$ Véase Miguel Pastrana Flores, Historias de la conquista. Aspectos de la historiografía de tradición náhuatl (México: Universidad Nacional Autónoma de México, Instituto de Investigaciones Históricas, 2004), especialmente “Motecuhzoma ante la conquista”, 119-209. 
ciones, alusiones o simples implicaciones respecto del tema de la entrega del poder entre los principales códices nahuas novohispanos que abordan el periodo; ${ }^{26}$ esto es válido para obras tan relevantes como el Lienzo de Tlaxcala, las Pinturas tlaxcaltecas de la conquista, el Códice Vaticano A, el Códice Telleriano Remensis, o el Códice Azcatitlan ${ }^{27}$ como para códices menos conocidos, pero que tampoco señalan el evento, como los Anales de Tula, el Códice en Cruz o la Tira de Tepechpan. ${ }^{28}$ Tampoco se menciona el acto de entrega del poder en el famoso relato de la conquista recogido como Libro XII en la Historia general de las cosas de Nueva España de fray Bernardino de Sahagún; si bien se ha aducido que el discurso de recepción de Motecuhzoma a Cortés en dicho libro implica algún tipo de sumisión hacia el capitán extremeño, esto no es claro, pues las formas de salutación dirigidas a Cortés tienen notables semejanzas con aquellas con las que se recibía a los guerreros y pochtecas triunfantes. ${ }^{29}$ Incluso, en la versión corregida del texto,

${ }^{26}$ Una visión historiográfica de conjunto de estos materiales en Miguel Pastrana Flores, “Códices anotados del centro de México", Historiografía mexicana I. Historiografía novohispana de tradición indígena, coordinación de José Rubén Romero Galván (México: Universidad Nacional Autónoma de México, Instituto de Investigaciones Históricas, 2003), 51-84. Según Patrick Johansson, la escena del Códice Vaticano A, donde en el año ce ácatl, uno caña, está la figura de un español a caballo, que blande una espada y porta un estandarte; en frente está un indígena con actitud de ofrecer al castellano un collar, y esta figura tiene el nombre de Motecuhzoma; esto representa que el gobernante está "humillado" frente al conquistador. Me parece que la escena es demasiado esquemática para sacar unas conclusiones tan tajantes. Véase Johansson, "8 de noviembre de 1519. El encuentro de Cortés con Motecuhzoma", Arqueología Mexicana, v. XXVII, n. 160 (noviembre-diciembre 2019), 24.

${ }^{27}$ Lienzo de Tlaxcala, edición facsimilar, edición de Alfredo Chavero, Artes de México. La conquista de México, número especial, año, xı, n. 51-52 (1964); Códice Vaticano A. 3738, edición facsimilar (México: Fondo de Cultura Económica; Akademische Druck-und Verlagsanstalt, 1996); Códice Azcatitlan, edición facsimilar, introducción de Michel Graulich, comentarios de Robert H. Barlow y Michel Graulich, traducción de Leonardo López Luján, 2 v. (París: Bibliothèque Nationale de France; Société des Américanistes, 1995), www.amoxcalli.org.mx y www.wdl.org.

${ }^{28}$ Anales de Tula, edición facsimilar, comentario por Rudolf van Zantwijk (Graz: Akademische Druck-und Verlagsanstalt, 1979), 1; Codex en Cruz, edición facsimilar, edición de Charles E. Dibble, 2 v. (Salt Lake City: Universidad de Utah, 1981); Tira de Tepechpan. Códice colonial procedente del valle de México, edición facsimilar, edición y comentarios de Xavier Noguez, 2 v. (Toluca: Instituto Mexiquense de Cultura, 1996).

${ }^{29}$ Véase Pastrana, Historias de la conquista, 145-149; Bernardino de Sahagún, Historia general de las cosas de Nueva España, edición de Juan Carlos Temprano, 2 v. (Madrid: Historia 16, 1990), libro XII, cap. XVI; II:969-971. Cfr. Johansson, "8 de noviembre de 1519", 21 , piensa que según el texto sahaguntino "Motecuhzoma cedía voluntariamente su imperio a Cortés". 
conocida como Relación de la conquista de esta Nueva España como la contaron los soldados indios que estaban presentes de 1585, en la cual, según fray Bernardino, "se hicieron varios defectos, y fue que algunas cosas se pusieron en la narración de esta conquista que fueron mal puestas, y otras se callaron, que fueron mal calladas", ${ }^{30}$ no se menciona el discurso de recepción; quizá fuera una de esas cosas “mal puestas". Además, es adecuado señalar que a este discurso de recepción no le sigue una ceremonia o ritual que confirme la supuesta entrega del mando. Por otra parte, el cronista chalca Chimalpáin Cuauhtlehuanitzin, en la copia autógrafa con anotaciones y variantes que hizo de la obra de Gómara, no agrega ningún comentario u observación respecto de los pasajes de la conquista que aquí se estudian y comentan; ${ }^{31}$ lo cual podría implicar una de dos cosas, que Chimalpain estaba de acuerdo con esa versión o que no tenía información adicional justamente porque en la tradición histórica chalca no se mencionaba el tema.

Hay dos excepciones notables, las obras de fray Diego Durán y de Fernando de Alva Ixtlilxóchitl. El primero menciona expresamente la entrega del poder del tlahtoani en estos términos: "Motecuhzoma se le sujetó y se rindió al servicio de Su Majestad desde aquella hora"; ${ }^{32}$ sin embargo, hay que hacer algunos matices, pues no es claro si en esa parte de su obra el dominico continúa usando la llamada "Crónica X", texto en náhuatl de raigambre mexica, como fuente principal; lo que sí es claro es que utiliza una mayor cantidad y calidad de fuentes hispanas, entre ellas el testimonio de su hermano de hábito fray Francisco de Aguilar, antiguo conquistador, el cual, a su vez, sigue la interpretación cortesiana. Por ello no es posible afirmar

${ }^{30}$ Bernardino de Sahagún, Relación de la conquista de esta Nueva España, como la contaron los soldados indios que se hallaron presentes. Convirtióse en lengua española, llana é inteligible y bien enmendada en este año de 1585, edición, estudio introductorio, notas, índices y apéndices de Miguel Pastrana Flores, Al lector. Véase Pastrana, "Las cosas mal dichas y mal calladas. Las diferencias entre la primera y la segunda versiones de la Relación de la conquista de Nueva España de fray Bernardino de Sahagún”, en El mundo de los conquistadores. La península ibérica en la Edad Media y su proyección en la conquista de América, edición de Martín Ríos (Madrid: Silex; Universidad Nacional Autónoma de México, Instituto de Investigaciones Históricas, 2015), 85-95.

${ }^{31}$ Véase Chimalpáhin y la conquista de México. La crónica de Francisco López de Gómara comentada por el historiador nahua, edición de Susan Schroeder, David Tavárez y Cristián Roade-la-Carrera, prólogo de José Rubén Romero Galván (México: Universidad Nacional Autónoma de México, Instituto de Investigaciones Históricas, 2012), cap. 66, 202-203; cap. 93, 245.

${ }^{32}$ Diego Durán, Historia de las Indias de la Nueva España e islas de la tierra firme, introducción, paleografía, notas y vocabularios de Ángel M. Garibay, 2a. ed., 2 v. (México: Porrúa, 1984), v. II, Historia, cap. LXXIV, 541. 
si la mención a la entrega del poder se corresponde con la tradición tenochca de la "Crónica X" o a la versión hispana que le transmitió Aguilar. ${ }^{33}$

Por su parte Ixtlilxóchitl, de sus cinco obras históricas, sólo en su Historia de la nación chichimeca relata la entrega del poder y menciona el discurso de vasallaje de Motecuhzoma. ${ }^{34}$ Sin embargo, debe advertirse que en este punto el tetzcocano sigue muy de cerca a Gómara sin que aparentemente agregue elementos de origen acolhua. ${ }^{35}$ Por otra parte, en el Compendio histórico del reino de Texcoco don Fernando dice que Motecuhzoma "se ofreció a ser amigo del emperador". ${ }^{36}$ Esto es muy ambiguo, y por ello no contribuye a aclarar el tipo de relación establecida entre las partes. En cambio, todas estas obras, y otras fuentes de tradición indígena, son fundamentales para conocer el contexto social, conceptual, político, religioso e institucional del ejercicio del poder entre los antiguos nahuas al momento del contacto con el mundo mediterráneo.

\section{Fundamentos del poder político en el mundo náhuatl}

De manera general, puede decirse que para los antiguos nahuas el mando político y su práctica estaban vinculados, de manera orgánica e indisoluble, con múltiples aspectos de su sociedad y cultura. Pueden reconocerse como más importantes los siguientes:

${ }^{33}$ Pastrana, Historias de la conquista, 185-187. La obra de contraste es la de Hernando de Alvarado Tezozómoc, pero ésta no abarca la llegada de Cortés a Tenochtitlan, véase Tezozómoc, Crónica mexicana, edición, introducción, notas y glosario de Gonzalo Díaz Migoyo y Germán Vázquez (Madrid: Historia 16, 1997); Robert H. Barlow, "La Crónica X”: versiones coloniales de la historia de los mexica tenochca”, en Los mexicas y la Triple Alianza, de Robert H. Barlow, edición de Jesús Monjarás-Ruiz et al. (México: Instituto Nacional de Antropología e Historia; Universidad de las Américas, 1990), 13-27; José Rubén Romero, "La Crónica X", en José Rubén Romero Galván, ed., Historiografía mexicana I. Historiografía novohispana de tradición indígena (México: Universidad Nacional Autónoma de México, Instituto de Investigaciones Históricas, 2003), 185-195.

${ }^{34}$ Fernando de Alva Ixtlilxóchitl, Historia de la nación chichimeca, en Fernando de Alva Ixtlilxóchitl, Obras históricas, edición, estudio introductorio y apéndices de Edmundo O'Gorman, 2a. ed., 2 v. (México: Universidad Nacional Autónoma de México, Instituto de Investigaciones Históricas, 1985), II: 216, 224-225.

35 Pastrana, Historias de la conquista, 203-206.

${ }^{36}$ Fernando de Alva Ixtlilxóchitl, Compendio histórico del reino de Texcoco, en Fernando de Alva Ixtlilxóchitl, Obras históricas, edición, estudio introductorio y apéndices de Edmundo O’Gorman, 2a. ed., 2 v. (México: Universidad Nacional Autónoma de México, Instituto de Investigaciones Históricas, 1985), I: 452. 
Primero, ${ }^{37}$ el poder político tenía su fundamento en las manifestaciones y las fuerzas de los seres sobrehumanos. Efectivamente, para los antiguos pueblos mesoamericanos el poder tenía un carácter divino o sagrado. Se veía como una transmisión o donación divina. Esto se manifestaba en diferentes textos sobre el mando político e implicaba la presencia de diversos dioses, no sólo de Quetzalcóatl, como tanto se ha dicho, sino también de Tezcatlipoca, Huitzilopochtli, Xiuhtecuhtli, Cihuacóatl, Tláloc y Xipe Tótec, por lo menos. ${ }^{38}$ Esto permite afirmar a Alfredo López Austin que los gobernantes eran "delegados de los dioses". ${ }^{39}$

Segundo, para poder ejercer el mando se requería que el tlahtoani recibiera y concentrara, en su propio cuerpo, una cantidad importante de fuerzas y entidades anímicas sacras. Efectivamente, los antiguos nahuas concebían el cuerpo humano como receptáculo de esas fuerzas y entidades; esto ocurría en cada ser humano, pero se incrementaba en el caso del gobernante, condición que resume fray Diego Durán al decir que "no es fábula decir que a sus señores tenían por dioses, porque en realidad, de verdad, los adoraban como a dioses". ${ }^{40}$ En ese sentido, hay abundantes referencias sobre la concentración de fuerzas sagradas en el cuerpo mismo del tlahtoani. Por ejemplo, están las menciones a que sus pies no podían tocar directamente el suelo; esto tiene que ver con la idea de fuerzas sagradas que habitan en él y que impedían el contacto directo con la realidad mundana. De igual manera, el que no pudiera ser visto directamente a los ojos se conecta precisamente con esta idea, pues a través de su mirada el tlahtoani podía transmitir parte de su fuerza y causar enfermedades e incluso la muerte a

${ }^{37}$ En este punto me baso principalmente, además de las obras de tradición indígena, en los siguientes trabajos María del Carmen Herrera Meza, Alfredo López Austin y Rodrigo Martínez Baracs, "El nombre náhuatl de la Triple Alianza”, Estudios de Cultura Náhuatl (Universidad Nacional Autónoma de México, Instituto de Investigaciones Históricas, México), v. 46 (julio-diciembre 2013), 7-35; Alfredo López Austin, La constitución real de MéxicoTenochtitlan, prólogo de Miguel León-Portilla (México: Universidad Nacional Autónoma de México, Instituto de Historia, 1961), “Organización política del altiplano central de México durante el Posclásico”, en Jesús Monjarás-Ruiz y otros, Mesoamérica y el centro de México. Una antología (México: Instituto Nacional de Antropología e Historia, 1985), 197-234.

38 Véase Daniel Alatorre Reyes, "El rito de ascenso al poder de los tlatoque mexica y los dioses que participaban en él" (tesis de maestría en Estudios Mesoamericanos, Universidad Nacional Autónoma de México, Posgrado en Estudios Mesoamericanos, 2014), 16-42.

${ }^{39}$ Alfredo López Austin, Cuerpo humano e ideología. Las concepciones de los antiguos nahuas, 2a. ed., 2 v. (México: Universidad Nacional Autónoma de México, Instituto de Investigaciones Antropológicas, 1984), I:83-85.

${ }^{40}$ Durán, Historia de las Indias, Historia, cap. XXII; II:188. 
la gente común. Esto también se ve en el primer encuentro entre Motecuhzoma y Cortés ocurrido sobre la calzada de Iztapalapa: el capitán se apea del caballo para abrazar al tlahtoani, pero es detenido por dos jefes nahuas, para impedir un contacto físico que sería riesgoso, posiblemente fatal, para el castellano, habida cuenta de la concentración de fuerza sacra de Motecuhzoma. Cortés lo cuenta de esta manera: "Y como nos juntamos yo me apeé y le fui a abrazar solo, y aquellos dos señores que con él iban me detuvieron con las manos para que no lo tocase". ${ }^{41}$ Gómara captó parte de la sacralidad del acto al escribir, "Cortés [...] fuéle a abrazar a nuestra costumbre. Los que le traían del brazo lo detuvieron, que no llegase a él, que era pecado tocarle". ${ }^{42}$ En tanto que Juan de Torquemada lo dice más claramente: "Los que le llevaban del brazo le detuvieron porque les pareció que eran gran pecado que hombre alguno le tocase, porque le tenían como a cosa divina". ${ }^{43}$ De manera complementaria, la misma acción de tocar al capitán extremeño implica que el contacto físico directo con él no se consideraba peligroso para los dignatarios nahuas. ${ }^{44}$

Tercero, tener un fundamento de linaje. Para aspirar al poder era indispensable pertenecer a un linaje de prestigio, principalmente de raigambre tolteca, como desde Alfredo Chavero se ha insistido entre los historiadores modernos. ${ }^{45}$ Lo anterior, si bien en lo general es correcto, también es cierto que no era suficiente, pues también eran relevantes las líneas de descendencia vinculadas a otros personajes prestigiosos, como el de Xólotl

${ }^{41}$ Cortés, "Segunda carta”, 208-209. Por su parte Bernal Díaz del Castillo lo refiere así: "Y cuando [...] le iba a abrazar, y aquellos grandes señores que iban con el Montezuma detuvieron el brazo a Cortés, que no le abrazase, porque lo tenían por menosprecio". Díaz del Castillo, Historia verdadera, cap. LXXXviII, I:312. Nuevamente las obras de tradición indígena no mencionan el asunto.

${ }^{42}$ Gómara, Historia de la conquista, cap. LXv, 109.

${ }^{43}$ Juan de Torquemada, Monarquía indiana, de los veinte y un libros rituales y monarquía indiana, con el origen y guerras de los indios occidentales, de sus poblazones, descubrimiento, conquista, conversión y otras cosas maravillosas de la mesma tierra firme, edición de Miguel León-Portilla y otros, 7 v. (México: Universidad Nacional Autónoma de México, Instituto de Investigaciones Históricas, 1975-1983), libro IV, cap. XLVI, II:152.

${ }^{44} \mathrm{Si}$ bien en un momento posterior se dice que el tlahtoani llevó de la mano al capitán, esto no se hizo ante la multitud, sino en privado.

${ }^{45}$ Alfredo Chavero, Historia antigua y de la conquista, en Vicente Riva Palacio y otros, México a través de los siglos. Historia general y completa del desenvolvimiento social, político, religioso, militar, artístico, científico y literario de México desde la antigüedad más remota hasta la época actual, 1a. reimp., 16 v. (México: Cumbre, 1987), libro IV, cap. III, II:234. Chavero se basa en las obras conocidas como Origen de los mexicanos y Relación de la genealogía y linaje que fueron publicadas en el siglo xıx por Joaquín García Icazbalceta. 
para los Acolhuas, o el de Tezozómoc de Azcapotzalco entre los tepanecas. En todo caso no puede afirmarse que los castellanos fueran considerados parte de linajes prestigiosos toda vez que no eran conocidos, además de dar amplias muestras de desconocer el protocolo náhuatl y por casi no llevar mujeres españolas entre ellos que les permitieran establecer nexos matrimoniales recíprocos con los aliados indígenas.

Cuarto, como es ampliamente conocido, el sistema para la sucesión en el mando entre los mexicas consistía en un sistema de deliberación y designación colectiva efectuado por el tlahtocan, también conocido como "consejo de los cuatro" o "consejo supremo", el cual, en condiciones normales, estaba constituido por el huey tlahtoani, el cihuacóatl, cuatro grandes dignatarios llamados tlachocalcatl, tlacatécatl, tlillancalqui y ezhuahuacatl. Para la designación de un nuevo gobernante también intervenían los tlatoque de Tetzcoco y Tlacopan, casi con seguridad también los mandatarios de otras ciudades de la cuenca de México, como Itztapalapa y Ehecatépetl, también los sumos sacerdotes del huey teocali de Tenochtitlan, el Tláloc tlamacazqui y Totec tlamacazqui, también intervenían los techutlatoque, los achcaucauhtin y los yaotequihua. Por ello puede inferirse que en caso de un recambio en el cargo del huey tlahtoani también debían participar para que la deliberación y la decisión final se llevara al cabo. Hasta donde es posible saber no hay menciones, alusiones o indicios de la participación del tlahtocan en una ocasión tan importante como la supuesta cesión de poder de Motecuhzoma en favor de Carlos I o de Cortés. ${ }^{46}$ Además, en el caso de la designación del tlahtoani la decisión del tlahtocan se consideraba inspirada por las deidades, y por ello era inapelable y no podía revestirse, pues como dicen los textos sahaguntinos "[...] los reyes y señores que te eligieron y señalaron y ordenaron por inspiración y ordenación de nuestro señor Dios, cuya elección no se puede casar [abrogar] ni variar por haber sido por ordenación divina [...]". ${ }^{47}$

Quinto, todo lo anterior exigía una fuerte carga de ritualidad y ceremonial para la transmisión del poder y su ejercicio público, lo cual igualmente implicaba un complejo ritual, tanto para el manejo de las fuerzas sagradas que se concentraban en el gobernante como para el ejercicio público de sus diferentes actividades y ocupaciones. Esto se reflejaba en varias de las fun-

${ }^{46}$ Sobre el tlahtocan, véanse Tezozómoc, Crónica mexicana, cap. 17, 109; Durán, Historia de las Indias, Historia, cap. XI, II:103; Sahagún, Historia general, libro vIII, cap. XVIII, II:596.

${ }^{47}$ Sahagún, Historia general, libro vi, cap. X, II:517. 
ciones y prerrogativas fundamentales del gobernante. Efectivamente, entre los antiguos nahuas el tlahtoani era mucho más que el principal mandatario político; también fungía como sumo sacerdote en las ceremonias públicas más relevantes, pues presidía diversos rituales vinculados a la renovación del mundo natural y de la sociedad. Además era juez de última instancia dentro del sistema normativo nahua, así las penas de muerte tenían que ser ratificadas por él. Por todo ello era visto como la cabeza del cuerpo social y el "corazón de la ciudad"; 48 esto es, se le consideraba el centro de conciencia y toma de decisiones del conjunto de la sociedad mexica y de Tenochtitlan.

Por otra parte, es claro que el pensamiento náhuatl contemplaba mecanismos, condiciones e instancias por las cuales un gobernante investido ritualmente como tal podía llegar a perder el poder. ${ }^{49}$ Debido a su trascendencia ritual, política y social, ésta era siempre una decisión de carácter colectivo; sólo las máximas autoridades del Excan Tlahtoloyan podían ordenar la ejecución de un tlahtoani y su linaje; por ello puede inferirse que, en caso de necesidad, forzosamente el tlahtocan tenía que estar involucrado en la posible muerte del gobernante. Al respecto es pertinente mencionar un huehuetlahtolli, "discurso antiguo", recogido por fray Bernandino de Sahagún, donde se habla de las consecuencias de la mala actuación de un tlahtoani..$^{50}$ En algunos casos parece que podían intervenir los ancianos líderes de los calpulis del común de la población, pidiendo a una autoridad superior, como el Excan Tlahtoloyan, la ejecución de un gobernante y su linaje por incumplir sus obligaciones.

Todo lo anterior implicaba necesariamente la muerte del gobernante en turno y de todo su linaje para poder designar a otro mandatario. Al parecer no hay ejemplos de tradición y tiempos mesoamericanos de transmisión o pérdida del poder de gobernantes vivos en favor de otros gobernantes, ni entre los mayas del clásico ni entre los mixtecos o zapotecos. ${ }^{51}$

${ }^{48}$ Sahagún, Historia general, libro VI, cap. X, II:518.

${ }^{49}$ Véase Miguel Pastrana Flores, “ ‘Para que descanse su corazón y su cuerpo'. Reflexiones en torno a la ejecución de los gobernantes en el mundo náhuatl”, en María Elena Vega Villalobos y Miguel Pastrana Flores, coords., El gobernante en Mesoamérica. Representaciones $y$ discursos del poder (México: Universidad Nacional Autónoma de México, Instituto de Investigaciones Históricas, 2018), 121-158.

${ }^{50}$ Sahagún, Historia general, libro vi, cap. v, II:497-499.

${ }^{51}$ Pastrana, " 'Para que descanse su corazón y su cuerpo'”. Véase Alfonso Caso, Reyes y reinos de la Mixteca, 1a. reimp., edición y advertencia de Ignacio Bernal (México: Fondo de Cultura Económica, 1984), sobre todo el Diccionario biográfico que comprende más de 300 
La situación se complica porque en el caso que se analiza se trataría de una supuesta transmisión voluntaria del poder del principal gobernante mesoamericano del momento en favor de una figura desconocida, Carlos I, a través de un personaje como Cortés, del cual los nahuas en concreto sabían muy poco y a quien, como hemos visto, no consideraban depositario de fuerzas sacras equivalentes a las de Motecuhzoma.

\section{Motecuhzoma ante los extraños}

Para evaluar la factibilidad de la entrega del poder, en primer término debe recordarse lo que ya todos sabemos: el gobernante estaba preso junto con muchos otros mandatarios pertenecientes al Excan Tlahtoloyan, especialmente los del ámbito de la cuenca de México. En efecto, el capitán castellano, siguiendo la tradición de la guerra renacentista, no sólo apresó a Motecuhzoma, sino que tomó como prisioneros a otros importantes gobernantes y dignatarios, los cuales, sin duda, estaban bajo una fuerte coerción física, política y psicológica de parte de Cortés, por lo cual no puede admitirse que sus actos fueran libres.

Por otra parte, es necesario evaluar si el huey tlahtoani tenochca tenía la autoridad suficiente para tomar de manera unipersonal una decisión tan radical como enajenar el poder de todo el Excan Tlahtoloyan a favor de un desconocido por intermedio de un recién llegado. Recordemos que "el lugar del mando de triple cede" era una institución política muy compleja que incluía otros dos huey tlahtocáyotl, Tlacopan y Tetzcoco, los cuales tenían su propia estructura y jerarquía de mando, además de múltiples tlatocáyotl y tecuhcáyotl que eran parte de esta peculiar institución, todos con sus propios gobernantes. Esto tiene mucho que ver con la manera como se ha concebido a esta formación política, militar y jurídica, si se trata de un "imperio" gobernado por un "autócrata”, o si se trata de una confederación, de un estado segmentario o de otra institución. El propio Cortés no tenía una idea clara de la naturaleza ni de la estructura de mando, por lo cual apresó a todos los gobernantes y mandatarios que pudo para intentar controlar la situación a su favor. Hasta donde se sabe, las grandes decisiones eran discutidas, sopesadas y tomadas de manera colectiva; por lo tanto, lo más 
probable es el que mismo huey tlahtoani no tuviera la autoridad suficiente para quitar el poder a todos los demás mandatarios del Excan Tlahtoloyan.

Además, si bien desde Francisco López de Gómara se ha insistido mucho en la idea de que Motecuhzoma y los mexicas pensaron que Cortés era Quetzalcóatl, ${ }^{52}$ esto no es del todo claro, pues en muchas obras tanto de tradición indígena como hispana hay suficientes elementos para dudar de esta identificación. ${ }^{53}$ El propio capitán nada dice acerca de este tema. También es muy discutible el tiempo que pudo durar tal confusión, si es que la hubo, si fue sólo durante los primeros contactos en la costa del golfo, o hasta la alianza con Tlaxcala, la cual se efectuó en términos de un pacto político-militar entre iguales, ${ }^{54} \mathrm{o}$ hasta la matanza de Cholula, que era, como se sabe, el principal santuario de Quetzalcóatl en Mesoamérica y, por ello, difícilmente podría pensarse que la deidad misma atacara a su propia ciudad. Debe recordarse como, según el testimonio del propio Cortés, Motecuhzoma afirmó que en su concepto los hispanos eran, al igual que él, hombres comunes y no seres extraordinarios, "veisme aquí que so [sic por soy] de carne y hueso como vos y cada uno, y que soy mortal y palpable". ${ }^{55}$ Finalmente, como dirían los abogados, admitiendo sin conceder que tal identificación existiera y se mantuviera hasta la supuesta entrega del poder, es necesario reconocer que, si bien Quetzalcóatl es un dios estrechamente vinculado al mando político, no es la única deidad con ese nexo, también participan, como ya se ha dicho, entidades tan importantes como Tezcatlipoca, Huitzilopochtli, Cihuacóatl, Xiuhtecuhtli y Xipe Tótec; por ello la transferencia del poder tendría que hacerse con la participación de todas estas entidades y no de una sola; sin embargo, no hay referencias a ritos, ceremonias, invocaciones, llamados, oraciones, símbolos o simples alusiones a estas deidades en el supuesto acto de transferencia del poder.

Por otra parte, admitiendo hipotéticamente la identificación del capitán con Quetzalcóatl, debe recordarse que este también era el modelo del

${ }^{52}$ Gómara, Historia de la conquista, cap. Xxvi, 47. “[...] decían que venía el dios Quetzalcouatl con sus templos a cuestas; que era dios del aire, que se había ido, y le esperaban.”

${ }^{53}$ Véase Pastrana, Historias de la conquista, especialmente "La naturaleza de los españoles”, 65-117. Para una opinión favorable a la identificación, véase Miguel León-Portilla, "Quetzalcóatl-Cortés en la conquista de México”, Historia Mexicana xxıv, n. 1 (julio-septiembre 1974), 13-35.

${ }^{54}$ Véase Miguel Pastrana Flores, "El inicio de la alianza hispano-tlaxcalteca. Una reinterpretación”, Centro de Estudios de Historia de México CARso, en prensa.

${ }^{55}$ Cortés, Cartas, “Segunda relación”, 211. 
sacerdocio en el mundo náhuatl; ${ }^{56}$ por lo tanto, la supuesta traslación del mando y, por ende, de funciones implicaría que también se le transmitía a Cortés la condición de sumo sacerdote de los dioses nahuas, lo cual es, a todas luces, un despropósito ya que implicaría una total contradicción desde las perspectivas náhuatl e hispánica respecto de las políticas, los discursos y las acciones emprendidas por el capitán extremeño en relación con las imágenes sagradas de los dioses nahuas y sus lugares de culto, pues a las primeras las trataba de destruir mientras que pretendía convertir a los segundos en sitios de adoración de las imágenes cristianas; para los nahuas tales acciones eran sacrilegios incomprensibles, mientras que para los hispanos eran muestras de celo y devoción.

Además, conforme a los fundamentos del poder entre los nahuas, no se trataría solamente de un cambio de mando político entre simples seres humanos, sino de mover las fuerzas sagradas y anímicas que sustentan el poder de un reservorio humano a otro. Motecuhzoma, en su calidad de huey tlahtoani, no podía simplemente renunciar a su condición en favor de otra persona, sino que tendría que desprenderse de las fuerzas sacras que le daban la condición misma de gobernante; de ahí que se diga al nuevo mandatario que ha pasado por todas las fases rituales, que ha accedido a una nueva condición que lo aleja de los seres humanos comunes. ${ }^{57}$ Por ello, los gobernantes debían ser ejecutados para que se desprendieran de las fuerzas y entidades anímicas que se concentraban en ellos, pues de lo contario seguirían siendo peligrosos, en tanto receptáculos vivos de fuerzas, energías y entidades sagradas que fundamentan el poder y el mando político. En ese sentido cabe reflexionar que, así como la transmisión de poder en el mundo náhuatl implicaba un complejo ritual, cabría esperar un ritual similar o equivalente para poder efectuar la transferencia del mando de Motecuhzoma a Cortés, pero no hay ninguna mención, noticia o simple alusión a ello ni en los textos hispanos ni en las obras de tradición indígena.

Poco antes de la llegada de la expedición de Pánfilo de Narváez enviada por Diego Velázquez para apresar a don Hernando, Gómara y Bernal Díaz refieren que Motecuhzoma le pidió a Cortés que se marchara de Tenochtitlan y de toda la región, pues tanto los mexicas como otros pueblos

56 Véase Miguel Pastrana Flores, Entre los hombres y los dioses. Acercamiento al sacerdocio de calpulli entre los antiguos nahuas (México: Universidad Nacional Autónoma de México, Instituto de Investigaciones Históricas, 2008), 67-68.

${ }^{57}$ Sahagún, Historia general. 
de la cuenca de México y los mismos dioses nahuas estaban muy enojados y ya se planeaba la muerte de los castellanos; Gómara refiere que las palabras del tlahtoani fueron las siguientes: "Ruégoos que os vayáis de esta mi ciudad y tierra, que mis dioses están de mí muy enojados porque os tengo aquí; pedidme lo que quisiereis, y dároslo he, porque mucho os amo; y no penséis que os digo esto burlando, sino muy de veras. Por ende, que así se haga en todo caso". ${ }^{58}$

Si efectivamente Motecuhzoma hubiera transferido su calidad de huey tlahtoani a Cortés - esto es, su condición de máximo gobernante, de sumo sacerdote y de juez supremo, entre otras-, tal petición resultaría inexplicable, pues ya no tendría la autoridad para hacerla, pero, si según los testimonios hispanos lo hizo, implica que aún conservaba, por lo menos de forma nominal y a sus propios ojos, la autoridad y la legitimidad suficientes para hacer semejante petición. En otros términos, o no había ocurrido la transmisión de poder que se le atribuye o, por lo menos, no se había efectuado de manera completa ni aceptable para el resto de los mexicas. Por todo lo anterior es claro que Cortés coaccionó a los dignatarios indígenas presos para llevar a cabo un auto legal de vasallaje que justificara sus acciones, pero este auto fue totalmente incompatible con la propia naturaleza del mando político en el mundo náhuatl, y careció completamente de significado y valor para los mexicas y sus aliados.

\section{La pérdida del poder}

Por todo lo anterior puede afirmarse que, desde la óptica náhuatl, Motecuhzoma no entregó el mando a Cortés ni se dio por vasallo de Carlos I, ni podía hacerlo. En ese sentido queda pendiente una cuestión, misma que puede expresarse con la siguiente pregunta: ¿̨cuál fue el proceso por el cual el tlahtoani perdió el poder? y, de manera complementaria, ¿̇en qué momento se dio la ruptura? Para ello se deben revisar muy brevemente diversos episodios que van desde el secuestro del tlacatecuhtli por Cortés hasta su muerte, pasando por la matanza del Templo Mayor. Los primeros indicios de una paulatina pérdida de autoridad se mencionan justamente después de haber sido apresado por los castellanos; primero se manifiesta

${ }^{58}$ Gómara, Historia de la conquista, cap. xCIv, 149; Díaz del Castillo, Historia verdadera, cap. CVIII, 396. 
como una resistencia de la administración tenochca para proveer a los castellanos de los bastimentos que requerían, según lo cuenta el texto náhuatl del Códice florentino: "Pero los principales a quienes mandaba esto, ya no le hacían caso, sino que estaban airados, ya no le tenían acatamiento, ya no estaban de su parte. Ya no era obedecido. Y, sin embargo, llevaban en bateas, daban aquello que se requería. Cosas de comer, cosas de beber y agua y pastura para los caballos". ${ }^{59} \mathrm{El}$ jesuita Juan de Tovar lo corrobora en su obra:

[...] y así tomaron vehementemente sospecha del trato de los Españoles començando los Yndios de temor a esconderse y faltar en acudir a lo necesario por los Españoles. Començavan a padecer hambre, especialmente los caballos y perros de ayuda que trayan consigo que eran muchos muy feroces y diestros en la guerra; llegó a tanto que fue necesario fuesen los Yndios amigos con algunos Mexicanos a buscar bastimentos. $^{60}$

Otro momento importante que permite sostener que la autoridad de Motecuhzoma como huey tlahtoani empezó a ser cuestionada es la noticia del intento de Cacama, tlahtoani de Tetzcoco para liberar al huey tlahtoani e incluso enfrentar con las armas a las fuerzas hispano-tlaxcaltecas si fuera necesario, según Fernando de Alva Ixtlilxóchitl, "Visto por el rey Cacama el poco ánimo y determinación de los mexicanos, se salió de la ciudad y se fue a Tetzcuco para juntar sus gentes, y con ellas libertar a su tío y nobleza mexicana de la servidumbre y afrenta en que vivían". ${ }^{61}$ Poco después Cacama fue apresado antes de poder llevar al cabo sus propósitos.

También debe recordarse la petición, ya mencionada, de Motecuhzoma a Cortés para que se marchara con los suyos de tierras nahuas; según Bernal Díaz, el gobernante mexica dijo lo siguiente:

${ }^{59}$ Fray Bernardino de Sahagún, "Libro doce. En él se dice cómo se hizo la guerra en esta ciudad de México”, en Bernardino de Sahagún, Historia general de las cosas de Nueva España, edición de Ángel M. Garibay, 4 v. (México: Porrúa, 1956), IV:79-165; cap. XVII, 110-111. Véase Sahagún, Historia general, libro XII, cap. 17, II:971-972. "Y los piles y achcauhtles y otros oficiales, a quien concernía esta provisión, no quería obedecer a Motecuçoma ni llegarse a él, pero con todo esto proveían de todo lo necesario."

${ }^{60}$ Juan de Tovar, Manuscrito Tovar. Origines et croyances des indiens du Mexique, edición de Jacques Lafaye (Graz: Akademische Druck-u Verlagsanstalt; Unesco, 1972), 80.

${ }^{61}$ Ixtlilxóchitl, Historia de la nación chichimeca, cap. LXXXVI, 223. 
¡Oh, señor Malinche y señores capitanes, cuánto me pesa de la respuesta y mando que nuestros teules han dado a nuestros papas e a mí e a todos mis capitanes! $\mathrm{Y}$ es que os demos guerra y os matemos, o os hagamos ir por la mar adelante. Lo he colegido dello y le paresce es que, que antes que comiencen la guerra, que luego salgáis desta cibdad y no quede ninguno de vosotros aquí. Y esto, señor Malinche, os digo que hagáis en todas maneras, que os conviene; si no mataros han. E mirá que os va las vidas. ${ }^{62}$

Lo que implica que la posición del gobernante estaba siendo cuestionada por diversos sectores de la sociedad tenochca y posiblemente también por el resto de las fuerzas políticas del Excan Tlahtoloyan.

Cuando Cortés parte a la costa del golfo para enfrentar y finalmente vencer a Narváez, Pedro de Alvarado quedó a cargo de la ciudad lacustre y de los rehenes. Como es conocido, los indígenas pidieron permiso para realizar la fiesta de Tóxcatl, una de las más importantes, pues se conmemoraba el nacimiento de Huitzilopochtli, el dios patrón de los mexicas, además de ser la fiesta de Tezcatlipoca, uno de principales dioses vinculados al poder político. Ya fuera porque Alvarado pensara que se preparaba una emboscada en su contra y entró en pánico, como se infiere de los soldados cronistas, o porque estaba loco y era malvado como dicen algunas fuentes indígenas, o por algún otro motivo, el caso es que los españoles mataron a los mexicas mientras realizaban el ritual, lo cual causó un impacto enorme, causó grandes pérdidas humanas en la élite de mando y provocó una reacción violenta, pues en cuanto se supo el incidente la población enardecida atacó a las fuerzas hispano-tlaxcaltecas y las sitió en sus aposentos, pues, como dicen los informantes de Sahagún:

Y cuando se supo fuera, empezó una gritería:

-Capitanes, mexicanos... venid acá: ¡Que todos armados vengan: sus insignias, escudos, dardos...! ¡Venid acá de prisa, corred: muertos son los capitanes, han muerto nuestros guerreros...! Han sido aniquilados, oh capitanes mexicanos.

Entonces se oyó el estruendo, se alzaron gritos, y el ulular de la gente se golpeaba los labios. Al momento fue el agruparse, todos los capitanes, cual si hubieran sido citados: traen sus dardos, sus escudos. Entonces la batalla empieza. ${ }^{63}$

${ }^{62}$ Díaz del Castillo, Historia verdadera, cap. CviII, 396. Gómara, Historia de la conquista de México, cap. xcıv, 149.

${ }^{63}$ Sahagún, "Libro doce”, cap. Xx, IV:117. 
Una vez iniciada la reacción de los habitantes de Tenochtitlan contra la ocupación hispano-tlaxcalteca ya no fue posible detenerla. Después de vencer a Narváez, Cortés regresó a Tenochtitlan, los mexicas permitieron que el capitán y sus hombres entraran en Tenochtitlan para, acto seguido, aislarlos y cortarles los suministros, lo cual también implica un deterioro en las capacidades de mando del tlahtoani. El capitán extremeño pide a Motecuhzoma que se normalicen las actividades de la ciudad, especialmente el mercado de Tlatelolco para garantizar el abasto de alimentos. Pero el tlahtoani dice que debe enviar a alguien de confianza que se haga cargo del asunto; Cortés accede y, según la Crónica de la Nueva España de Francisco Cervantes de Salazar, "Invió Motezuma a su hermano, el señor de Eztapalapa, al cual, como vieron fuera los mexicanos [...] no le dexaron volver a la prisión ni hicieron el tianguez; antes le eligieron por su caudillo y Capitán [...]”. ${ }^{64}$ Esto es, a Cuitláhuac, a quien se le encomienda reabrir el mercado y regresar al campamento español, pero no cumple con las disposiciones de Cortés ni regresa, y de inmediato se reanudan las hostilidades contra los castellanos. Torquemada aclara que, una vez libre, Cuitláhuac coordinó la resistencia tenochca a las fuerzas ocupantes hispanoindígenas, pues cuando "Cortés (sin pensamiento de malicia) soltó a un hermano de Motecuhzuma, señor de Itztapalapa y los mexicanos le eligieron por su caudillo". ${ }^{5}$ Por su parte, Bernardino Vásquez de Tapia, en sus declaraciones en el juicio de residencia del marqués, deja entrever que el tlahtoani, ante los malos tratos a los que se hallaba sometido por parte de Cortés, dispuso el ataque de los mexicas contra los castellanos sin que se preocuparan por su seguridad personal:

[...] e visto por el dicho Motunzuma el poco remedio quel dicho don Hernando Cortés ponía, envió a decir a los indios, como hombre questaba descontendo e desesperado de verse preso e las cosas como iban, que hiciesen lo que quisiesen e que no hiciesen cuenta dél, e desde allí en adelante los indios comenzaron a matar de los cristianos por do quiera que podían e se levantó la cibdad e toda la tierra contra los cristianos. ${ }^{66}$

${ }^{64}$ Cervantes de Salazar, Crónica de la Nueva España, cap. civ, 466. Véase Genaro García, Carácter de la conquista española en América y en México según los textos de los historiadores primitivos, prólogo de Andrés Henestrosa, edición facsimilar (México: Fundación Miguel Alemán, 1990), 211-214.

65 Torquemada, Monarquía indiana, libro IV, cap. LXVIII, II:209.

66 "Algunas respuestas de Bernardino Vázquez de Tapia”, en Documentos cortesianos, II:35, 107-108. 
Así, a pesar de los esfuerzos de Cortés, sus huestes seguían sitiadas. Por ello pide que Motecuhzoma que salga al techo del recinto donde están atrincherados y hable a la multitud para calmarla; el primero en hablar es el señor de Tlatelolco, quien pide el cese de hostilidades y anuncia la presencia del huey tlahtoani. Sin embargo, al salir, el efecto fue muy diferente. Así lo cuenta Sahagún: "Oídas estas vozes por los mexicanos y tlatlilulcas, començaron entre sí a bravear y maldezir a Motecuçoma, diciendo: ‘¿Qué dize el puto de Motecuçoma, y tú vellaco con él? No cesaremos la guerra'. Luego començaron a dar alaridos y a tirar saetas y dardos hacia donde estaba que hablava, junto con Motecuçoma". ${ }^{67}$

Más allá de la disputa sobre quién mató a Motecuhzoma, si los españoles con una espada o los mexicas con piedras, lo relevante para este estudio es que aquí es donde realmente podemos constatar una ruptura entre el huey tlatoani preso y las instituciones políticas de la sociedad mexica, pues desde este momento el personaje ya no es obedecido por los mexicas. El ser denostado hace evidente una severa erosión de su autoridad y su legitimidad, condiciones indispensables para ejercer el mando político, lo que lleva a la pérdida efectiva del poder mismo.

$\mathrm{Al}$ respecto debe señalarse que, desde su cautiverio Motecuhzoma ha incurrido en graves faltas en sus responsabilidades como huey tlahtoani, principalmente en lo que toca a cuatro aspectos fundamentales; primero, ha descuidado el ejercicio de la guerra pues no sólo no se han emprendido nuevas campañas, sino que varios pueblos se han rebelado y en la ciudad están aposentados sus acérrimos enemigos, los tlaxcaltecas; segundo, no ha cumplido con la impartición de justicia conforme a las reglas y principios normativos nahuas - Cortés ha juzgado e incluso ejecutado a altos dignatarios, como Cuauhpopoca, sin observar las reglas-; tercero, no ha cumplido con sus obligaciones religiosas, especialmente no se ha continuado el culto público estatal y los sacrificios a los dioses de manera escrupulosa, pues han sido obstaculizados por los cristianos; cuatro, la sola presencia de un ejército hispano-indígena pone en entredicho la seguridad

${ }^{67}$ Sahagún, Historia general, libro XII, cap. 21, II:975. Tovar, Manuscript Tovar, 81. “[...] un valeroso capitán llamado Quiuihtémoc, de edad de diez y ocho años, a quien ya querían elegir por rey, dixo en alta boz: '¿Qué es lo que dice ese vellaco de Motecuçuma, mujer de los Españoles, que tal se puede llamar pues con ánimo mujeril se entregó a ellos de puro miedo y asegurándonos nos ha puesto a todos en este trabajo? Ya no le queremos obedecer porque no es nuestro Rey, y como vil hombre le hemos de dar el castigo." 
de la ciudad, especialmente por la presencia de sus acérrimos enemigos los tlaxcaltecas. Todos estos aspectos eran causales para perder el poder entre los antiguos nahuas. ${ }^{68}$

Las obras de tradición española, por su propia perspectiva, no tocan el asunto; mientras que las obras de tradición indígena, si bien dan pistas sobre lo que ocurrió entre la élite de mando, sólo permiten vislumbrar que se trata de un proceso más complejo de un paulatino debilitamiento político de Motecuhzoma, que es catalizado por la matanza de Templo Mayor, ante la cual puede inferirse que los sacerdotes de Huitzilopochtli expresaron un mandato divino por el cual las fuerzas de los dioses abandonaban al tlahtoani.

Las obras de tradición hispana ofrecen dos posibilidades para entender lo que ocurrió con la sucesión, una primera versión señala que, después de la muerte del huey tlahtoani, fue elegido Cuitláhuac, mientras que otras versiones dicen que estando vivo fue elegido el sucesor. La primera versión es respaldada por el testimonio de Cortés, quien escribió:

De los que en la cibdad de Buacachula [Huaquechula] se prendieron, en especial de aquel herido, supe muy por extenso las cosas de la grand cibdad de Timixtitlán, y cómo después de la muerte de Muteeçuma había subscedido en el señorío un hermano suyo señor de la cibdad de Yztapalapa que se llamaba Cuetravaçin [Cuitlahuatzin], el cual suscedió en el señorío porque murió en las puentes el hijo de Muteçuma que heredaba el señorío. ${ }^{69}$

Otros autores coinciden con el capitán, por ejemplo, Fernando de Alva Ixtlilxóchitl dice: "Idos los españoles, luego los mexicanos hicieron señor a un hermano de Moteczuma que se llamaba Cuitlahuatzin". ${ }^{70}$ También lo reitera Torquemada en tres ocasiones, en la primera fray Juan dice que eligieron a Cuitláhuac "por su caudillo", ${ }^{71}$ y no como tlahtoani; en la segunda oportunidad es el propio Motecuhzoma, quien responde a las

${ }^{68}$ Véase Pastrana, Historias de la conquista, 128-135; " 'Para que descanse su corazón'”, passim.

${ }^{69}$ Cortés, Cartas, "Segunda carta", 305.

${ }^{70}$ Sumaria relación de todas las cosas que han sucedido en la Nueva España, en Fernando de Alva Ixtlilxóchitl, Obras históricas, edición, estudio introductorio y apéndices de Edmundo O'Gorman, 2a. ed., 2 v. (México: Universidad Nacional Autónoma de México, Instituto de Investigaciones Históricas, 1985), I:390.

${ }^{71}$ Torquemada, Monarquía indiana, libro IV, cap. LXVIII, II:209. 
interrogantes de Cortés respecto de una posible sucesión mientras están sitiados: "Dijo que no se atreverían en México a elegir rey, siendo él vivo". Más adelante el franciscano precisa que el proceso sucesorio tuvo lugar después del regreso del ejército indohispano a Tlaxcala y que también se renovó el tlahtocan, dato interesante porque otras fuentes señalan que el "consejo supremo" se renovaba justamente en el momento de designación de un nuevo mandatario, "Lo primero fue que eligieron por su rey y señor un hermano menor de Motecuhzuma, llamado Cuitlahuatzin y otros cuatro senadores, que siempre estaban al lado del rey en todos los negocios". ${ }^{72}$

Por su parte, Bernal Díaz del Castillo en su Historia verdadera de la conquista de Nueva España afirma que, aun estando vivo Motecuhzoma, se nombró a Cuitláhuac como nuevo tlahtoani, pues al salir el primero para tratar de apaciguar a los mexicas pasó lo siguiente:

Y muchos principales y capitanes mexicanos bien le conoscieron [...] y llorando le dijeron: "¡Oh, señor e nuestro gran señor, y cómo nos pesa de todo vuestro mal y daño y de nuestros hijos y parientes! Hacemos os saber que ya hemos levantado a un vuestro pariente por señor". E allí le nombró cómo se llamaba, que se decían Coadlavaca [sic por Cuitláhuac], señor de Iztapalapa [... $]^{73}$

Considerando las características del gobernante, la naturaleza del poder entre los antiguos nahuas, la importancia de la ritualidad, así como los mecanismos de deliberación y designación colectiva desarrollados por el tlahtocan, es más consistente la versión que sostiene que fue después de la muerte de Motecuhzoma cuando se designó a un nuevo mandatario. De tal suerte que, aparentemente y hasta donde es posible saberlo, fue entre la salida del cautiverio del señor de Iztapalapa y la presencia del "señor sañudo" en el balcón cuando fue apedreado, el momento culminante del proceso de pérdida del poder de Motecuhzoma, causado por el deterioro paulatino de su autoridad y su legitimidad. ${ }^{74}$ Por ello la designación y la investidura de Cuitláhuac como nuevo tlahtoani debió ocurrir, necesariamente, después de su muerte.

72 Torquemada, Monarquía indiana, libro IV, cap. LXX, II:212; libro IV, cap. LXXIV, II:232.

${ }^{73}$ Díaz del Castillo, Historia verdadera, cap. Cxxvi, I:472-473.

${ }^{74}$ Estos acontecimientos ocurrieron lugar entre el 24 y el 28 de junio de 1520. 


\section{Para cerrar}

Para Cortés y la Corona española la entrega del poder de Motecuhzoma era fundamental para explicar y justificar los eventos militares que condujeron a la caída de Tenochtitlan, así como la constitución de la Nueva España como parte integrante del naciente dominio español de ultramar, incluso era indispensable en la constitución misma de la noción de un imperio que no dependiera del antecedente del sacro imperio romano, sino de la sesión de un imperio indiano en favor de la Corona de Castilla. Sin embargo, puede deducirse que aún para la Corona tanto la plena veracidad como la completa legalidad de las acciones y palabras de Cortés estaban en duda; por ello, en varios momentos los descendientes de Motecuhzoma tuvieron que refrendar la entrega del poder en favor de los reyes castellanos. Al respecto, véase lo que dice en el siglo XVII el jesuita Diego Luis Motezuma, descendiente del tlahtoani:

Y ha sido sobre todos los demás, de tan superior aprecio el título de su derecho por la renuncia del Emperador Motezuma, que, para restablecerle y más fijarle, a instancia del señor rey don Felipe IV y de su Real Consejo de Indias, hizo nueva renuncia de todo su derecho a la corona mexicana en la real casa de Castilla el conde de Motezuma, tercer nieto de aquel Emperador. ${ }^{75}$

La relevancia de la entrega del poder de Motecuhzoma en favor de la Corona española se mantuvo hasta comienzos del siglo XIX. Al respecto es conveniente recordar cómo, al invadir las tropas napoleónicas la península ibérica y abdicar el rey Carlos IV y el príncipe heredero Fernando en favor de los franceses, se inició un debate en los dominios americanos respecto de la legalidad del hecho y la transmisión de la soberanía. Los criollos novohispanos sostuvieron que el pacto inicial entre los gobernantes y los gobernados estaba roto y debía volverse a los fundamentos mismos de esa relación. Por otra parte, desde lo que se conoce del mundo político mesoamericano en general y de los antiguos nahuas en particular, dicha entrega del poder, en los términos referidos y asumidos por los españoles, aparece como francamente imposible, impracticable, o por lo menos como extremadamente dudosa.

75 Diego Luis Motezuma, Corona mexicana o Historia de los nueve Motezumas, edición facsimilar, edición y prólogo de Lucas de la Torre (Valladolid: Maxtor, 2012), 452. 
Así puede decirse que para el mundo hispano la entrega del poder era una necesidad política, legal e historiográfica de primer orden, indispensable para justificar y explicar en términos jurídicos, políticos, militares e incluso personales la naciente Nueva España, mientras que para el mundo mesoamericano simplemente era una imposibilidad desde la perspectiva sacra, ritual, política y social de la naturaleza misma del poder y del ejercicio del mando. Por ello, puede decirse que la explicación de lo que pasó con la estructura de mando mexica y del Excan Tlahtoloyan entre la entrada de las fuerzas hispano-indígenas a Tenochtitlan y la toma del poder de Cuitláhuac, pese a los ríos de tinta que han corrido, aún está por dilucidarse.

CRONOLOGÍA MÍNIMA APROXIMADA ${ }^{76}$

1519

18/23 de septiembre

Recibimiento de los castellanos en Tlaxcala y establecimiento de la alianza hispano-tlaxcalteca.

16/18 de octubre

Matanza de Cholula.

8 de noviembre

Llegada de la alianza hispano-indígena a Tenochtitlan y encuentro entre Motecuhzoma y Hernando Cortés.

14 de noviembre

Prisión de Motecuhzoma.

1520

Enero-abril

Supuesta entrega del poder de Motecuhzoma.

Principios de mayo

Llegada de la expedición de Pánfilo de Narváez.

5/9 de mayo

Petición de Motecuhzoma a Cortés para que se marche.

10 de mayo

Salida de Cortés a Cempoala para combatir a Narváez.

$15 / 20$ de mayo

Matanza de Templo Mayor.

24 de junio

Regreso de Cortés a Tenochtitlan.

${ }^{76}$ La cronología de la conquista presenta inexactitudes, casi todas las fechas son aproximadas. Me baso en José Luis Martínez, Hernán Cortés, 1a. reimp. (México: Universidad Nacional Autónoma de México; Fondo de Cultura Económica, 1992), 239, 283-284, y en mis propias inferencias. 
Cronología. Continuación...

$27 / 28$ de junio

30 de junio

8 de julio

Julio

30 de octubre
Muerte de Motecuhzoma.

Victoria mexica y huida del ejército hispanoindígena en la Noche Triste.

Regreso del ejército hispano-indígena a Tlaxcala.

Designación de Cuitláhuac como nuevo tlahtoani.

Cortés firma su Segunda relación en Segura de la Frontera (Tepeaca).

\section{Bibliografía}

Aguilar, Francisco de. Relación breve de la conquista de la Nueva España. Serie de Historiadores y Cronistas de Indias, 7. Edición, estudio preliminar, notas y apéndices por Jorge Gurría Lacroix. México: Universidad Nacional Autónoma de México, Instituto de Investigaciones Históricas, 1980.

Alatorre Reyes, Daniel. "El rito de ascenso al poder de los tlatoque mexica y los dioses que participaban en él.” Tesis de maestría en Estudios Mesoamericanos. Universidad Nacional Autónoma de México, Posgrado en Estudios Mesoamericanos, 2014.

Alva Ixtlilxóchitl, Fernando de. Compendio histórico del reino de Texcoco. En Obras históricas de Fernando de Alva Ixtlilxóchitl. Historiadores y Cronistas de Indias, 4. Edición, estudio introductorio y apéndices de Edmundo O'Gorman. 2a. ed., 2 v. México: Universidad Nacional Autónoma de México, Instituto de Investigaciones Históricas, 1985.

Alva Ixtlilxóchitl, Fernando de. Historia de la nación chichimeca. En Obras históricas de Fernando de Alva Ixtlilxóchitl. Historiadores y Cronistas de Indias, 4. Edición, estudio introductorio y apéndices de Edmundo O'Gorman. 2a. ed., 2 v. México: Universidad Nacional Autónoma de México, Instituto de Investigaciones Históricas, 1985.

Alva Ixtlilxóchitl, Fernando de. Sumaria relación de todas las cosas que han sucedido en la Nueva España. En Obras históricas de Fernando de Alva Ixtlilxóchitl. V. I. Historiadores y Cronistas de Indias, 4. Edición, estudio introductorio y apéndices por Edmundos O’Gorman. 2a. ed., 2 v. México: Universidad Nacional Autónoma de México, Instituto de Investigaciones Históricas, 1985.

Anales de Tula. Fontes Rerum Mexicanorun, 1. Edición facsimilar con comentario de Rudolf van Zantwijk. Graz: Akademische Druck und Verlagsanstalt, 1979. 
Añón, Valeria. "Prólogo" y "Notas". En Segunda carta de relación y otros textos de Hernán Cortés. La Inteligencia Americana, 2. Buenos Aires: Corregidor, 2010. Barlow, Robert H., “ ‘La Crónica X’: versiones coloniales de la historia de los mexica tenochca." En Los mexicas y la Triple Alianza, de Robert H. Barlow. Obras de Robert H. Barlow, 3. Edición de Jesús Monjarás-Ruiz et al. México: Instituto Nacional de Antropología e Historia/Universidad de las Américas, 1990.

Casas, Bartolomé de las, De thesauris. Obras completas, 11.1. Fijación del texto, traducción, introducción e índices de Ángel Losada, con notas e índices de Martín Lassegue. Madrid: Alianza Editorial, 1992.

Caso, Alfonso. Reyes y reinos de la Mixteca. Sección de Obras de Antropología. Edición y advertencia de Ignacio Bernal. 1a. reimp., 2 v. México: Fondo de Cultura Económica, 1984.

Cervantes de Salazar, Francisco. Crónica de la Nueva España. Biblioteca Porrúa, 84. Prólogo, de Juan Miralles Ostos. México: Porrúa, 1985.

Chavero, Alfredo. Historia antigua y de la conquista. En México a través de los siglos. Historia general y completa del desenvolvimiento social, político, religioso, militar, artístico, científico y literario de México desde la antigüedad más remota hasta la época actual de Vicente Riva Palacio y otros. V. I-III. 1a. reimp., 16 v. México: Cumbre, 1987.

Chimalpáhin y la conquista de México. La crónica de Francisco López de Gómara comentada por el historiador nahua. Serie Historiadores y Cronistas de Indias, 10. Edición de Susan Schroeder, David Tavárez y Cristián Roa-de-la-Carrera. Prólogo de José Rubén Romero Galván. México: Universidad Nacional Autónoma de México: Instituto de Investigaciones Históricas, 2012.

Codex en Cruz. Edición facsimilar, ed. de Charles E. Dibble. 2 v. Salt Lake City: Universidad de Utah, 1981.

Códice Azcatitlan. Edición facsimilar. Introducción de Michel Graulich, comentarios de Robert H. Barlow y Michel Graulich, traducción de Leonardo López Luján. 2 v. París: Bibliothèque Nationale de France/Société des Américanistes, 1995, www.amoxcalli.org.mx y www.wdl.org.

Códice Vaticano A. 3738. Códices Mexicanos, XII. Edición facsimilar. México: Fondo de Cultura Económica; Akademische Druck-und Verlagsanstalt, 1996.

Cortés, Hernán. Cartas de relación. Clásicos Castalia, 198. Edición, introducción y notas de Ángel Delgado Gómez. Madrid: Castalia, 1993.

Delgado Gómez, Ángel, “Introducción” y “Notas”. En Cartas de relación de Hernán Cortés. Clásicos Castalia, 198. Edición, introducción y notas de Ángel Delgado Gómez. Madrid: Castalia, 1993.

Díaz del Castillo, Bernal. Historia verdadera de la conquista de la Nueva España. Clásicos de la Lengua Española. Edición, presentación, estudio y notas de Gui- 
llermo Serés, con ensayo introductorio de Miguel León-Portilla. 2 v. México: Academia Mexicana de la Lengua, 2014.

Documentos cortesianos. Edición de José Luis Martínez. 4 v. México: Fondo de Cultura Económica/Universidad Nacional Autónoma de México, 1990.

Durán, Diego. Historia de las Indias de la Nueva España e islas de la tierra firme. Biblioteca Porrúa, 36-37. Introducción, paleografía, notas y vocabularios de Ángel M. Garibay. 2a. ed., 2 v. México: Porrúa, 1984.

Elliott, John H. "Cortés, Velázquez and Charles V." En Hernán Cortés, Letter from Mexico. XI-XXXVII. Traducción, edición y una nueva introducción de Anthony Pagden. New Haven: Yale University Press, 2001.

Elliott, John H. "Cortés, “The Mental World of Hernán Cortés." Royal Historical Society Transactions. Fifth Series, v. 17 (1967): 41-58.

Esparza, José Javier. La cruzada del océano. La gran aventura de la Conquista de América. Historia, 170. 2a. ed. Madrid: La Esfera de los Libros, 2017.

Fernández de Oviedo y Valdés, Gonzalo. Historia general y natural de las Indias. Biblioteca de Autores Españoles. Edición de Juan Pérez de Tudela. Madrid: Atlas, 1959.

Frankl, Víctor. "Hernán Cortés y la tradición de las Siete Partidas." Revista de Historia de América (Instituto Panamericano de Geografía e Historia, México), n. 53-54 (julio-diciembre 1962): 9-7.

Frankl, Víctor. "Imperio particular e imperio universal en las cartas de relación de Hernán Cortés". Cuadernos Hispanoamericanos. Madrid: Instituto de Cultura Hispánica, n. 165 (septiembre 1963): 443-482.

García, Genaro. Carácter de la conquista española en América y en México según los textos de los historiadores primitivos. Biblioteca Mexicana de la Fundación Miguel Alemán. Edición facsimilar. Prólogo de Andrés Henestrosa. México: Fundación Miguel Alemán, 1990.

Gillespie, Susan. Los reyes aztecas. La reconstrucción del gobierno en la historia mexica. Traducción de Stella Mastrangelo. México: Siglo XXI, 1986.

Graulich, Michel. Moctezuma. Apogeo y caída del imperio azteca. Traducción de Tessa Brisac. México: Era; Instituto Nacional de Antropología e Historia, 2014. Grunberg, Bernard. Histoire de la conquête du Mexique. París: L’Harmattan, 1995. Guzmán, Eulalia. "Prólogo" y "Aclaraciones y rectificaciones". En Relaciones de Hernán Cortés a Carlos V sobre la invasión de Anáhuac. Edición de Eulalia Guzmán. México: Libros Anáhuac, 1958.

Herrera Meza, María del Carmen, Alfredo López Austin y Rodrigo Martínez Baracs. "El nombre náhuatl de la Triple Alianza." Estudios de Cultura Náhuatl (Universidad Nacional Autónoma de México, Instituto de Investigaciones Históricas, México), v. 46 (julio-diciembre 2013): 7-35. 
Iglesia, Ramón. Cronistas e historiadores de la Conquista de México. El ciclo de Hernán Cortés. 1a. reimp. México: El Colegio de México, 1990.

Iglesia, Ramón. El hombre Colón y otros ensayos. Introducción de Álvaro Matute. México: Fondo de Cultura Económica, 1986.

Johansson, Patrick. " 8 de noviembre de 1519. El encuentro de Cortés con Motecuhzoma." Arqueología Mexicana xxviI, n. 160 (noviembre-diciembre 2019).

Konetzke, Richard. América Latina II. La época colonial. Historia Universal Siglo XXI, 22. Traducción de Pedro Scaron. 25a. ed. México: Siglo XXI, 1995.

León-Portilla, Miguel. "Quetzalcóatl-Cortés en la conquista de México." Historia Mexicana, v. xxiv, n. 1 (julio-septiembre 1974): 13-35.

Lienzo de Tlaxcala. Edición facsimilar. Edición de Alfredo Chavero. Artes de México. La conquista de México, número especial, año XI, n. 51-52 (1964).

López Austin, Alfredo. "Organización política del altiplano central de México durante el Posclásico." En Mesoamérica y el centro de México. Una antología, de Jesús Monjarás-Ruiz y otros. México: Instituto Nacional de Antropología e Historia, 1985.

López Austin, Alfredo. Cuerpo humano e ideología. Las concepciones de los antiguos nahuas. Serie Antropológica, 39. 2a. ed., 2 v. México: Universidad Nacional Autónoma de México, Instituto de Investigaciones Antropológicas, 1984.

López Austin, Alfredo. La constitución real de México-Tenochtitlan. Prólogo de Miguel León-Portilla. México: Universidad Nacional Autónoma de México, Instituto de Historia, 1961.

López de Gómara, Francisco. Historia de la conquista de México. Biblioteca Ayacucho, 65. Prólogo y cronología de Jorge Gurría Lacroix. 2a. ed. Caracas: Ayacucho, 1991.

Martínez Hoyos, Francisco. Breve historia de Hernán Cortés. Breve Historia. Madrid: Nowtilus, 2014.

Martínez, José Luis. Hernán Cortés. Breviarios, 519. 1a. reimp. México: Universidad Nacional Autónoma de México; Fondo de Cultura Económica, 1992.

Martínez, José Luis. Hernán Cortés: versión abreviada. México: Fondo de Cultura Económica, 1992.

Miralles, Juan. Hernán Cortés, inventor de México. V. I. Biblioteca ABC. Protagonistas de la Historia, 11-12. Prólogo de Fernando R. Lafuente. 2 v. [S. 1.]: Folio; ABC, 2004.

Montell, Jaime. La caída de México-Tenochtitlán. México: Joaquín Mortiz, 2003.

Montell, Jaime. La conquista de México Tenochtitlan. México: Miguel Ángel Porrúa, 2001.

Motezuma, Diego Luis. Corona mexicana o Historia de los nueve Motezumas. Edición facsimilar. Edición y prólogo de Lucas de la Torre. Valladolid: Maxtor, 2012. 
Orozco y Berra, Manuel. Historia antigua y de la conquista de México. Biblioteca Porrúa, 17-20. Edición y estudio previo de Ángel M. Garibay, biografía y bibliografías de Miguel León-Portilla. 2a. ed., 4 v. México: Porrúa, 1978.

Pagden, Anthony R. "Introduction" y "Notes". En Letter from Mexico de Hernán Cortés. XXXIX-LXXI. Traducción, edición y una nueva introducción de Anthony Pagden. New Haven: Yale University Press, 2001.

Pagden, Anthony R. Señores de todo el mundo. Ideologías del imperio en España, Inglaterra y Francia (en los siglos XVI, XVII y XVII). Historia, Ciencia y Sociedad, 260. Traducción de M. Dolors Gallart Iglesias. Barcelona: Península, 1997.

Pastrana Flores, Miguel. “'Para que descanse su corazón y su cuerpo'. Reflexiones en torno a la ejecución de los gobernantes en el mundo náhuatl." En El gobernante en Mesoamérica. Representaciones y discursos del poder. 121-158. Culturas Mesoamericanas, 9. Coordinación de María Elena Vega Villalobos y Miguel Pastrana Flores. México: Universidad Nacional Autónoma de México, Instituto de Investigaciones Históricas, 2018.

Pastrana Flores, Miguel. "Códices anotados del centro de México". En Historiografía mexicana. I. Historiografía novohispana de tradición indígena. Coordinación de José Rubén Romero Galván. México: Universidad Nacional Autónoma de México, Instituto de Investigaciones Históricas, 2003.

Pastrana Flores, Miguel. "El inicio de la alianza hispano-tlaxcalteca. Una reinterpretación", Centro de Estudios de Historia de México CaRso, en prensa.

Pastrana Flores, Miguel. "Las cosas mal dichas y mal calladas. Las diferencias entre la primera y la segunda versiones de la Relación de la conquista de Nueva España de fray Bernardino de Sahagún." En El mundo de los conquistadores. La península ibérica en la Edad Media y su proyección en la conquista de América, coordinación de Martín Ríos. 85-95. Madrid: Sílex/Universidad Nacional Autónoma de México, Instituto de Investigaciones Históricas, 2015.

Pastrana Flores, Miguel. Entre los hombres y los dioses. Acercamiento al sacerdocio de calpulli entre los antiguos nahuas. Serie de Cultura Náhuatl. Monografías, 30. México: Universidad Nacional Autónoma de México, Instituto de Investigaciones Históricas, 2008.

Pastrana Flores, Miguel. Historias de la conquista. Aspectos de la historiografía de tradición náhuatl. Serie de Teoría e Historia de la Historiografía, 2. México: Universidad Nacional Autónoma de México, Instituto de Investigaciones Históricas, 2004.

Pereyra, Carlos. Hernán Cortés. "Sepan cuantos...”, 165. Prólogo de Martín Quirarte. México: Porrúa, 2006.

Prescott, William H. Historia de la conquista de México. Historia y Cultura de América. Traducción de José María González de la Vega, con anotaciones de Lucas Alamán. 2 v. Buenos Aires: Imán, 1944. 
Restall, Matthew. Cuando Moctezuma conoció a Cortés. La verdad del encuentro que cambió la historia. Traducción de José Eduardo Latapí. México: Taurus, 2019. Rizo-Martínez, Lucía Ester. "El síndrome de Estocolmo: una revisión sistemática." Clínica y Salud 29, n. 2 (Madrid) (julio 2018), http://dx.doi.org/10.5093/clysa2018a12.

Romero Galván, José Rubén. “La Crónica X.” En Historiografía mexicana I. Historiografía novohispana de tradición indígena. Coordinación de José Rubén Romero Galván. México: Universidad Nacional Autónoma de México, Instituto de Investigaciones Históricas, 2003.

Sahagún, Bernardino de. Historia general de las cosas de Nueva España. Crónicas de América, 55. Edición de Juan Carlos Temprano. Madrid: Historia 16, 1990.

Sahagún, Bernardino de. Historia general de las cosas de Nueva España. Biblioteca Porrúa, 8, 9, 10, 11. Edición de Ángel M. Garibay. 4 v. México: Porrúa, 1956.

Sahagún, Bernardino de. Relación de la conquista de esta Nueva España, como la contaron los soldados indios que se hallaron presentes. Convirtióse en lengua española, llana é inteligible y bien enmendada en este año de 1585. Edición, estudio introductorio, notas, índices y apéndices de Miguel Pastrana Flores, en proceso.

Sepúlveda, Juan Ginés de. Historia del Nuevo Mundo. Alianza Universidad, 495. Introducción, traducción y notas de Antonio Ramírez de Verger. Madrid: Alianza, 1987.

Solís y Rivadeneira, Antonio de. Historia de la conquista de México, población y progresos de la América septentrional, conocida por el nombre de Nueva España. “Sepan cuantos...”, 89. Prólogo y apéndices de Edmundo O’Gorman, notas de José Valero Silva. 5a. ed. México: Porrúa, 1990.

Tapia, Andrés de. Relación de algunas cosas de las que acaecieron al Muy Ilustre Señor Don Hernando Cortés, Marqués del Valle, desde que se determinó ir a descubrir tierra en la Tierra Firme del mar Océano. En Crónicas de la Conquista de México. Biblioteca del Estudiante Universitario, 2. Introducción, selección y notas de Agustín Yáñez. México: Universidad Nacional Autónoma de México, 1939.

Tezozómoc. Crónica mexicana. Crónicas de América, 76. Edición, introducción, notas y glosario de Gonzalo Díaz Migoyo y Germán Vázquez. Madrid: Historia 16, 1997.

Thomas, Hugh. La conquista de México. Traducción de Víctor Alba. Barcelona: Patria, 1994.

Tira de Tepechpan. Códice colonial procedente del valle de México. Edición facsimilar. Biblioteca Nezahualcóyotl. Edición y comentarios de Xavier Noguez. 2 v. Toluca: Instituto Mexiquense de Cultura, 1996.

Torquemada, Juan de. Monarquía indiana, de los veinte y un libros rituales y monarquía indiana, con el origen y guerras de los indios occidentales, de sus poblazones, descubrimiento, conquista, conversión y otras cosas maravillosas de la mesma tierra 
firme. Historiadores y Cronistas de Indias, 5. Edición de Miguel León-Portilla et al. 7 v. México: Universidad Nacional Autónoma de México, Instituto de Investigaciones Históricas, 1975-1983.

Tovar, Juan de. Manuscrito Tovar. Origines et croyances des indiens du Mexique. Edición de Jacques Lafaye. Graz: Akademische Druck-u Verlagsanstalt/Unesco, 1972. Valero Silva, José. El legalismo de Hernán Cortés como instrumento de su conquista. Cuadernos. Serie Histórica, 13. México: Universidad Nacional Autónoma de México, Instituto de Investigaciones Históricas, 1965.

Vázquez Chamorro, Germán. Moctezuma. Madrid: Algaba, 2006.

Vázquez de Tapia, Bernardino. Relación de méritos y servicios del conquistador Bernardino Vázquez de Tapia. Nueva Biblioteca Mexicana, 34. Estudio y notas de Jorge Gurría Lacroix. México: Universidad Nacional Autónoma de México, 1972.

Zavala, Silvio. Hernán Cortés ante la justificación de su conquista. En Toribio Esquivel Obregón, Hernán Cortés y el derecho internacional en el siglo XVI. Presentación de Silvio Zavala. 2a. ed. México: Porrúa, 1985.

Zavala, Silvio. La filosofía política en la Conquista de América. Tierra Firme. Prólogo de Rafael Altamira. 3a. ed. México: Fondo de Cultura Económica, 1977.

Zavala, Silvio. Las instituciones jurídicas en la conquista de América. Biblioteca Porrúa, 50. 3a. ed. México: Porrúa, 1988. 